\title{
CHANGE IN THE OWNERSHIP POLICY PARADIGM IN POLAND: STATE CONTROL VS. PRIVATISATION
}

\author{
Piotr KOZARZEWSKI - Maciej BAŁTOWSKI \\ (Received: 27 January 2016; revision received: 5 November 2016; \\ accepted:16 January 2017)
}

\begin{abstract}
The paper presents an analysis of the shift in the ownership policy of the Polish government in office since 2015 towards a more active role of the state and a more reluctant attitude towards privatisation. This shift reflects a general change in the paradigm of the role of the state towards the concept of the state as a strong market player, which includes the strengthening of its ownership functions. Among others, it has led to stalling the privatisation process and concentrating only on its fiscal goals. Possible factors causing this statist shift are divided into two dichotomic groups: the government's good faith $v s$. the impact of rent-seeking interest groups and endogenous $v s$. exogenous factors. Our main conclusion is that despite similarities with the trends observed in some other countries, endogenous factors such as increasing capture of the state by rent-seeking groups, and not the exogenous ones, including the global financial crisis, contributed most to the growing statist trends in the Polish state's ownership policy.
\end{abstract}

Keywords: Poland, privatisation, ownership policy, post-communist transition, crony capitalism, rent-seeking, role of the state

JEL classification indices: D72, L33, P16, P31

Piotr Kozarzewski, corresponding author. Assistant Professor at the Faculty of Economics at the Maria Curie-Skłodowska University in Lublin, Poland, and a member of the Supervisory Council of Center for Social and Economic Research (CASE), Warsaw, Poland.

E-mail: pkozarzewski@umcs.lublin.pl

Maciej Baltowski, Professor, Head of the Theory and History of Economics Department of the Faculty of Economics at the Maria Curie-Skłodowska University in Lublin, Poland, and a member of the Council of the Polish Supreme Audit Office. E-mail: maciej.baltowski@umcs.lublin.pl 


\section{INTRODUCTION}

In many countries throughout the world, a general shift in national economic policies towards a more active role of the state is being witnessed - far beyond its previous regulating roles, acquiring more active and interventionist functions. Even though some moves in the opposite direction can also be seen (in countries where excessive state interventionism is seriously threatening the stability of public finances and development prospects), the overall balance between "pro-statist" and "pro-market" steps seems to be clearly in favour of the economically active state much more active than a decade ago. This shift, usually explained as the reaction to the global financial crisis, enjoys support from a number of the most renowned economists, including Nobel Prize winners Joseph Stiglitz (2009) and Paul Krugman (2009), who both contributed to the "resurrection" of Keynesian ideas.

The most important manifestations of this generally "pro-statist" trend include changes in the state's ownership policy and the growing importance of companies that are directly or indirectly controlled by the government. Following the period of a neoliberal standstill, we are witnessing "the return of state-owned enterprises" in the developed economies (Flores-Macias - Musacchio 2009). A wide discussion has started, looking for an efficient model of the so-called state corporate governance, which would, on the one hand, ensure efficient state impact on the economy and, on the other hand, help avoid dysfunctions of an economically active state (Musacchio - Lazzarini 2012). In Poland (and in some other post-communist countries) similar trends can be observed, and their importance for the state's economic policy may be much higher than in the developed economies. Before the recent statist turn, the withdrawal of the post-communist state from its ownership functions was not just part of the economic policy expected to meet the challenges of the changing economic and social conditions: it was the cornerstone of market reforms.

There are only a few articles devoted to the recent privatisation trends and the increasingly statist ownership policy of the state in transition economies. Two of them deserve special attention: the one on the Russian economy (Radygin Entov 2014), in which changes in the government's policy are analysed from the perspective of the evolution of contemporary theoretic approaches to the choice of an optimal form of ownership, and the study (Szanyi 2016) of the changing role of state, ownership, and privatisation in Hungary and Poland as a contribution to the development of the theory of Central and Eastern European capitalism models. Two other articles were devoted to selected issues of the statist shift: vested interests in privatisation (mostly in Poland) (Senderski 2015) and the differences between formal and real share of the state in the enterprise sector of the Polish economy (Bałtowski - Kozarzewski 2016). 
The aim of this paper is to contribute to the discussion on the factors which impact economic policy design and implementation in post-communist countries through analysing the Polish case, the shifts between its privatisation and state property management functions. The paper is organised as follows. Section 2 discusses the initial conditions and assumptions of the Polish state's ownership policy and its evolution towards statism. Section 3 analyses changes in the paradigm of the role of the state, which underlie the statist shift in the ownership policy. In Section 4, we try to identify the main factors behind these changes. Section 5 summarises the major findings and suggests topics for further research. Our hypothesis is that external factors such as the global economic downturn and, with some exceptions, the growing popularity of statist solutions in economic policy worldwide are only partially responsible for the statist shift in Poland. A combination of endogenous factors prevail, where, among a multitude of possible other factors, the increasing role of interest groups which receive rent from the state property seems to be of the greatest importance. Meanwhile, the growing imbalance in public finances may cause adverse effects, stimulating cautious privatisation as a source of revenues for the state budget.

\section{OWNERSHIP POLICY OF THE POLISH STATE: INITIAL ASSUMPTIONS AND EVOLUTION}

As in the majority of other transition countries, privatisation was regarded in Poland as the cornerstone of market reforms. At the end of the communist era, the Polish economy was mostly state property-based, with over $70 \%$ of the country's GDP produced by the state sector (the private sector remaining mostly in agriculture and small businesses). On the other hand, from the very beginning of the transition, there was a general understanding among the reformers that a market economy must be based on the dominance of private property.

The economic programme of the first post-communist government, the socalled Balcerowicz Plan, addressed privatisation issues in the context of creating market institutions which had withstood the test of time in Western economies. Following that simple course of thought, the main goal was of a systemic character: to contribute to the change of the economic system through the creation of private entities. Within this framework, a number of sub-goals existed, of which the most important was the change in the role of the state, which would withdraw from performing ownership functions for the majority of enterprises.

Despite its importance, the systemic goal was never explicitly set - in terms of what the ultimate ownership structure of the Polish economy should be and what the exact criteria were for keeping some sectors or even specific companies 
under state control. What is more, the government started, quite soon, to exclude enterprises regarded to be of key importance for the national interests (when their microeconomic efficiency was less important than their ability to perform economically and socially important tasks), thus limiting the possible scope of the de-statisation of the Polish economy. However, until the mid-2010s, the ruling political elites, regardless of their formal ideological self-identification, agreed that all state-owned enterprises, sooner or later, should be privatised apart from those that, for very important reasons, must remain under state control (although views on the size of the public domain and the essence of these reasons varied significantly). The time limits of privatisation were changing, too: from the initial intention to conduct it as fast as possible, within a few years, through opting out of setting time limits, to unsuccessful attempts to set the exact date of the completion of the privatisation policy. By contrast, the current government regards privatisation as basically completed and even accuses its predecessors of overprivatising the Polish economy (Jackiewicz 2016).

Polish privatisation policy had two important features. The first one, imposed by the law, was its gradualist, highly consensual character, where most of the privatisation deals had to be approved by insiders, and the interests of a wide range of stakeholders, including those outside the enterprise (e. g. its suppliers) were taken into account. Authors of this approach believed - unlike privatisation makers in many other post-communist countries such as the Czech Republic, Russia, or Hungary - that a slower pace resulting from careful preparation of privatisation deals (both in the technical and social dimensions) was much more important than a massive and rapid formal change of owners because the reformed market environment would exert strong pressure on state-owned enterprises and force them to adapt and restructure, thus making their privatisation less urgent, although still necessary (Murrell - Wang 1993).

The second feature was, at least during the first years of the transition, the multiplicity of goals. Apart from the purely systemic role, privatisation was expected to solve the problem of the microeconomic inefficiency of state-owned enterprises; this, in turn, would contribute to the rise in productivity of the entire enterprise sector. Privatisation also had other goals: political ones (creating a powerful pro-reform lobby of the actors involved in the privatisation process and benefitting from its results) and fiscal ones (treating the sale of state property as a source of income to the state budget).

During the first years of the transition, systemic and microeconomic goals seemed to be of key importance to the government, but starting from the second half of the 1990s, the privatisation processes became increasingly fiscally oriented. At the end of the 1990s, it was decided that privatisation revenues would finance certain government expenditures, among others, the ambitious social re- 
form programme - including the pension reform. Nevertheless, just a year after these reforms started, a new coalition came into office, which was openly opposed to continued privatisation. This approach, together with the falling demand for privatised property due to the world economic recession at the beginning of the 2000 s, resulted in a dramatic slowdown of the privatisation pace. It inevitably led to a decline in privatisation revenues and, among other negative consequences, to the inability to finance the social reform package with them.

After the more liberal-minded political forces re-gained power in 2007, privatisation dynamics temporarily increased, although meeting the fiscal goal was still the most important issue. Gradually, however, the coalition, which ruled for 8 years, began to lose interest in privatisation, even as a source of income. State interventionist ideas started to gain ground again. After this coalition lost the October 2015 elections, the new government dropped privatisation from its economic agenda.

In consequence, other goals, first of all long-term ones, started to lose their importance, to the point of disappearing completely by the end of 2015. The decline of the systemic goals was especially fast: in the new century, irrespective of whether the ruling coalition was more pro-statist or more (relatively) liberalminded, most of the largest privatisation deals were cases of "reluctant privatisation" (Bortolotti - Faccio 2004), which meant the transfer of ownership rights without the appropriate transfer of control rights. The main tool was keeping ownership control by selling only minority blocks of shares (Ministry of Treasury 2011). Other means were also used for the largest companies. For example, special provisions were included in the companies' charters granting special voting rights to the state owner. Since the late 1990s, the state also began to adopt legislation that granted it special control rights over companies of strategic importance to the economy, e.g. the right to block certain decisions (Battowski Kozarzewski 2016).

The microeconomic goals of privatisation also lost their importance. Despite the fact that studies (Bałtowski - Kozarzewski 2014; Patena - Błaszczyk 2016) confirmed the positive effects of privatisation at an enterprise level for a vast majority of privatisation deals, in the 2000 s, passing state property into private hands, especially those of foreign investors, started to be increasingly regarded by policymakers not as a positive process, but as a threat to national interests. The set of political goals has been forgotten and since the early 2000 s, both ruling coalitions and their major political rivals have no longer regarded the private sector as a source of political support.

The successes in building a market economy in the course of post-communist transition inevitably change the hierarchy of privatisation goals, making systemic and microeconomic ones less prominent, as the private sector becomes dominant 
in the ownership structure. In Poland, by the end of the 1990s, about two-thirds of the country's GDP was already produced by the private sector. In this situation, while privatisation is still going on, other goals, quite naturally, gain relative importance - first of all more short-term ones such as the possibility of privatisation to be an important source of state budget revenues.

However, it seems that systemic goals, which were (at least formally) part of the official policy of most governments until the end of 2015, are far from being fully reached. The share of the state sector in the country's GDP in Poland is not only still higher than in the majority of the most developed market economies, even those with strong state positions in the enterprise sector such as France (CEEP 2000; Kowalski et al. 2013), but also, according to the EBRD estimations and Eurostat data, ${ }^{1}$ higher than in the majority of CEE countries. Taking into account all forms of state control over enterprises, the state sector was estimated at about 15-20\% as of end-2012 (Bałtowski - Kozarzewski 2014), and since then no radical change has been seen. Besides, the progress of privatisation in Poland is very uneven across sectors and company size groups. While in manufacturing industries the state sector share of sales was $5.6 \%$ by the end of 2012, in extractive industries and in the infrastructure, it was still almost a half: $46.2 \%$ and $45.8 \%$, respectively (Bałtowski - Kozarzewski 2014). The bigger the enterprise, the more likely it is to be controlled by the state. In 2014, out of the 25 largest companies, nearly one-half (12) were under state control, and the share of sales and employment in this group was even larger: $64.4 \%$ and $62.3 \%$, respectively (Bałtowski - Kozarzewski 2016).

It can be argued that at least during the last 10 years only fiscal goals were systematically pursued. The ownership policy of the state was to a large extent subordinated to the fiscal needs of the government. First, since about 2003, the pace of privatisation has become visibly dependent on the state budget situation: a high budget deficit seems to be the main factor inclining the government to privatise - albeit reluctantly - while trying not to lose control over companies. Once the government balance improved, the government was losing incentives to sell shares (Figure 1).

Second, starting from 2005, the government began to intensively explore another source of income based on state property, i.e. dividend payments. Compared to proceeds from privatisation, it proved to be an easier way to raise funds for the budget because it was much less dependent on the global economic situation and it did not involve the need to reduce the size of the state-controlled sector. While plans for privatisation proceeds usually fell short of the target - sometimes very

Http://www.ebrd.com/what-we-do/economic-research-and-data/data.html; htp://appsso.eurostat.ec.europa.eunui/how.do?ataset=gov_10a_ggfa\&lang=en 


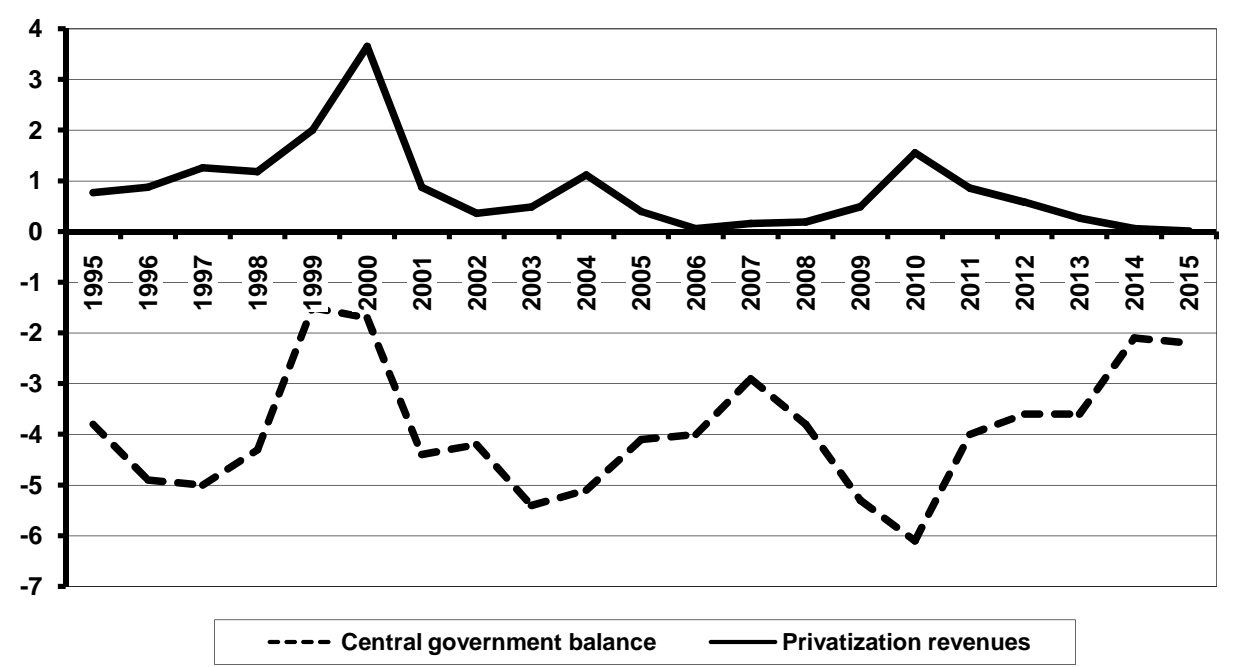

Figure 1. Privatisation revenues and the central government balance (percent of GDP)

Source: Ministry of Treasury, Eurostat, own calculations.

radically, as in 2006 and 2015, when the achievement of the targeted proceeds fell as low as $11 \%$ and $4 \%$, respectively, the plans for dividends were as a rule over-fulfilled (with the record set in 2009: $272 \%$ of the planned amount). During the most part of the analysed period, proceeds from dividends were higher than those from privatisation, and in 2014-2015, they virtually became the sole source of income within the state's ownership policy (Figure 2).

It seems quite obvious that the openly anti-privatisation and pro-statist stance of the new government, which was formed at the end of 2015 after the conservative Law and Justice (PiS) party won the elections, makes it even more difficult to use privatisation as a source of budget revenues. At the same time, the new government is challenged by the planned dramatic growth of expenditure (on ambitious investment and social programs). Thus, the government plans to extend the practice of stripping the state-controlled companies of profits (Jackiewicz 2016). So far, the fiscal situation of the government is far from being desperate: the central government deficit in 2015 amounted to $2.2 \%$ of the GDP and the corresponding figure expected for 2016 is about $2.8 \%$, but growing budgetary problems seem to be a very plausible scenario. In this case, will the government revert to the policy of using privatisation as an emergency source of income? 


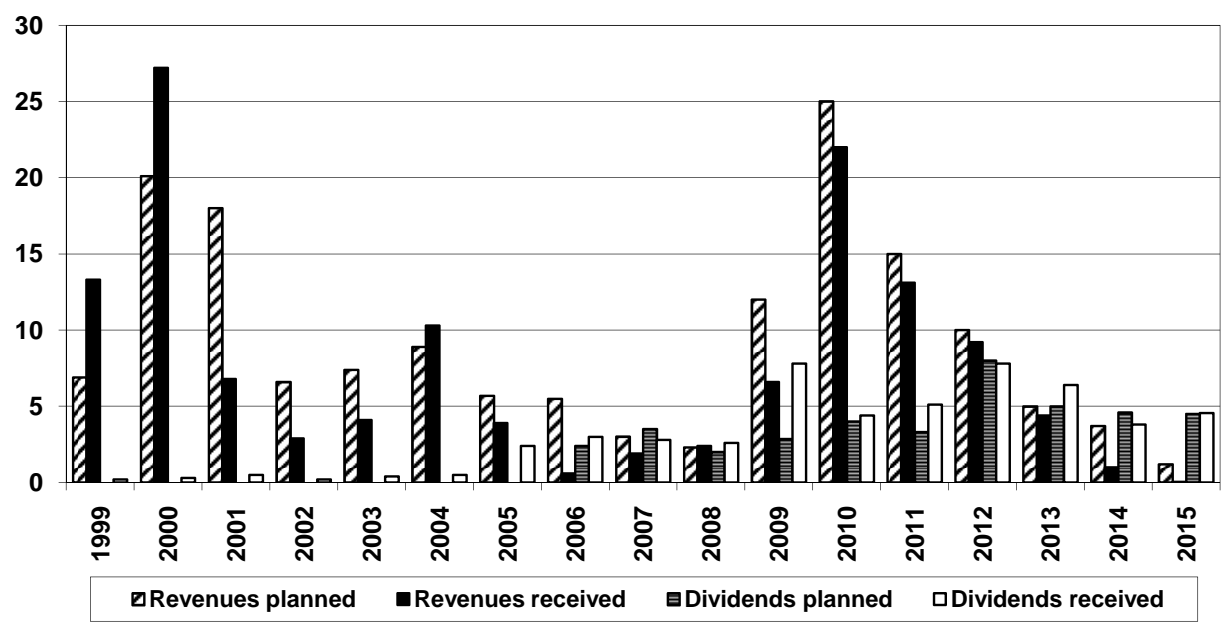

Figure 2. Revenues from privatisation and dividend payments (billion PLN, current prices; PLN/ EUR rate 4.26 on December 31, 2015)

Source: Ministry of Treasury, own calculations.

\section{CHANGES IN THE PARADIGM OF THE ROLE OF THE STATE IN THE ECONOMY}

Shifts in the hierarchy of privatisation goals (and in the attitude towards privatisation itself) seem to reflect broader changes in the economic policy, namely changes in the paradigm for the role of the state in the economy. The state no longer shuns direct control over business entities. It remains a powerful player on the market in a longer perspective - and even tries to expand its role. As we have shown above, since the early 2000s, privatisation started to lose its role of being the cornerstone of reformist economic policy. Its role became residual. In recent years, the government usually opted for privatisation only as part of crisis management, i.e. when it had no better solution to cope with its financial problems.

A striking observation is that there is a high degree of continuity between the Civic Platform (PO)-Polish People's Party (PSL) government's policy (20072015) and the new PiS government, despite all the ideological differences, so strongly stressed by representatives of these political forces. The former defined themselves as a rather centrist coalition, even with some elements of liberalism, while the latter are openly statist and conservative. Ironically, the statist shift under PiS adversaries, especially during the last years of the PO-PSL rule, was so deep that for the new government it seems, in many respects, to be enough to follow the already existing trends, just deepening and widening them. 
First, the shift in paradigm is evidenced by the above-mentioned abandonment of the complete privatisation of companies, especially when they can generate financial gains for the state budget. Since the beginning of the last decade, these companies have grown to be regarded, in the official discourse, as an object of high-return public investment, so their possible privatisation should be postponed until the indefinite future (Głombicki 2012; Prusek - Bielecki 2012). In line with these declarations, the dynamics of privatisation, even selling minority blocks of shares, started to decline mainly because of companies withdrawing from already approved privatisation plans and preparing less and less ambitious privatisation plans for the subsequent years. Just after the PiS government was formed, the new Minister of Treasury officially withdrew the last privatisation offer and declared the goal of "extinguishing the privatisation" (Jackiewicz 2016). The Ministry plans to sell only small blocks of shares that have no value for the state interests (Ministry of Treasury 2015a).

At the same time, the need to reconsider a number of recent years' privatisation deals has been declared by the new government. The main concern is allegedly the inadequate selling price and prejudice to national interests. These interests seem to be defined quite broadly, as the privatisation of a mountain cableway operator is one of the deals questioned for this reason. The revision of privatisation deals may take the form of contract re-negotiation or re-nationalisation through the buy-out of the previously privatised property, or even through termination of a privatisation contract (Sudak 2015).

Second, while declaring no nationalisation goals, the state gradually increases its ownership control, among others, through the acquisition of previously privatised enterprises by companies controlled by the Treasury. Until recently, this was explained as just "business decisions" to acquire companies, rather than as part of the statist economic policy. The largest deals include take-overs of two previously privatised power plants (the third such large deal in this branch is currently under way), and the creation of a financial group headed by the state-controlled PZU insurance company through the acquisition of private banks (three banks have been acquired so far, including Pekao S.A., the second largest commercial bank in Poland).

Third, since 2012, the state has declared an increased investment activity aimed, first of all, to speed up economic development through big public-private partnership investment projects (the "Polish Investments" program). Another direction is "rescue investments", where profitable state-owned companies are forced to enter into holdings with unprofitable ones. Under the PiS rule, a new Ministry of Development was created which prepared an ambitious "Strategy for Responsible Development". The document plans, among others, a very extensive 
state investment activity intended to lead to a "re-industrialisation" of the Polish economy (Ministry of Development 2016).

In the spirit of continuity, since the beginning of the present decade, a kind of economic xenophobia has started to develop. According to its proponents, the role of FDI in the Polish economy is too high, which may risk the country's national interests. So the economy should be "domesticated", or "re-Polonised," i.e. foreign investments should be replaced with domestic ones. Initially, this was supposed to involve only the banking sector, which was $80 \%$ private and $70 \%$ controlled by foreign capital, in order to protect the Polish banking sector from the impact of the financial turmoil abroad (Kawalec 2011). It should be noted, however, that this sector has proved to be very sound, politically independent, and well-functioning, including the time of the global financial crisis. Poland was the only post-communist country to avoid financial crisis during the whole $25+$ years of transition. After PiS came to power, the head of the newly created Ministry of Development coined the phrase "There is not enough Polish economy in the Polish Economy" (Morawiecki 2015) and the idea of its "domestication" became part of official policy also applied to other sectors. According to the "Strategy for Responsible Development," FDI activity should be limited to the sectors selected by the government (Ministry of Development 2016).

\section{REASONS FOR THE CHANGES}

The question about the roots of the paradigm shift and the corresponding policy changes still needs to be fully and comprehensively answered. There are particularly two areas where our knowledge is far from adequate and where there is no consensus among researchers and other observers and interpreters of economic policy in Poland. The first one is the extent to which these changes were introduced in good faith, and the possible role of various vested interests. The second area is the importance of domestic and exogenous roots of the statist trends.

\subsection{Good faith and vested interests}

One possible answer to the question of whether the policy shift was made in good faith or merely under the pressure of vested interests is that it originated mainly out of policymakers' sincere conviction that refraining from privatisation and increasing the role of the state as the owner (and market player) would help to eliminate numerous market failures, boost the growth of the national economy, and help to solve social issues; that the government needs a strong state sector 
from which to reap the necessary resources to conduct such an active economic and social policy. It also needs tools to neutralise external negative factors such as the adverse impact of the global crisis, the selfish behaviour of transnational investors, who may neglect Polish national interests, etc. This kind of justification can be found in official documents of the Polish government and interviews with top Polish politicians and government officials (Ministry of Development 2016; Morawiecki 2015). The statist policy shift also enjoys ideological and conceptual support from some Polish experts and members of academia, sometimes taking the form of a fierce ideological debate (Mączyńska 2016). Developed economies' experience also brings arguments in favour of this hypothesis because their history of state-controlled enterprise sector, albeit mixed, shows its development and crisis management potential (Mühlenkamp 2015). Last but not least, one can also draw attention to the fact that followers of a more statist ownership policy include former state officials with impeccable reputation as reformers (such as Stefan Kawalec and Jacek Socha, mentioned above) who would be unlikely to seek private gains from the policy change.

It should be noted, however, that even when the government acts in good faith, it may still create fertile ground for vested interests. For example, in the mid1990 s, the government significantly slowed down the demonopolisation of some sectors of the economy and even performed reconsolidation in coal mining, sugar refining, oil industry, ferrous metallurgy, and banking. The proclaimed goal was to create strong structures able to successfully compete on global markets and to raise their value before privatisation. In reality, it led to the creation of powerful interest groups within these sectors, which, in many cases, jeopardised the plans to restructure and privatise them (Kochanowicz et al. 2004).

Researchers have not thus far focused their attention on the good faith aspects of the Polish state's ownership policy. Instead, a number of publications exist where vested interests in this area are, at least in passing, analysed (Błaszczyk 2004; Kochanowicz et al. 2006; Bałtowski - Kozarzewski 2014), the latest being Marcin Senderski's (2015) paper. These studies represent the trend in the world literature that regards public property as a source of rent. Some of the most widespread ones seem to be, as described by Bortolotti - Pinotti (2003), political rents extracted by elected politicians who interfere with the functioning of state-controlled companies in order to satisfy the needs of certain interest groups. In Poland, it manifests itself, for example, in the extensive support for mostly unprofitable state-owned coal mines, their employees being regarded as a very important group of voters. This includes a set of measures aimed at keeping these companies alive and guaranteeing miners' high earnings and special social benefits. However, the question of the amount of good faith in these kinds of state intervention needs further investigation. 
Resources of state-controlled enterprises are also used to satisfy the interests of other groups, both those having direct connections (e.g. through financing investments) to the state-controlled enterprise sector, and those without such connections but considered valuable as voters (some professional groups, families with many children, football fans, etc.). It is done either directly, e.g. through sports sponsorship (Senderski 2015), or indirectly, through the state budget which redistributes taxes and dividends paid by these companies. To be able to distribute these resources, the government becomes interested in high profitability of at least some of the biggest state-controlled companies, which is achieved, among others, through preserving their monopolistic position on the market.

Resources of the state-controlled sector of the Polish economy may also serve to extract direct rents for the members of political elites. Already in mid-1990s, the winning political parties started to treat state assets as spoils that belong to the victors. Such loots included positions on supervisory boards of companies controlled by the Ministry of Treasury. In fact, this was not new: each consecutive winning coalition tried to change all state representatives on supervisory boards who had been appointed by their political rivals (Jarosz 2001). The new PiS government expanded this practice, applying it to top managers and positions in subsidiaries of state-controlled companies, at the same time lifting several requirements - both legal ones and those included in corporate charters - intended to ensure adequate qualifications of board members and to prevent political corruption (e.g. qualifying exams for supervisory board members and a ban on sitting on more than one board).

Summing up, it may be argued that the underlying cause of statist trends may be the current institutional setup, which is not inclusive enough, using the terms coined by Daron Acemoğlu and James A. Robinson (2012), in the sense that it does not secure a level ground for all economic players with their rights efficiently protected. What still seems to be strong (and even shows some growth tendencies) is extractive institutions which "are designed to extract incomes and wealth from one subset of society to benefit a different subset" (Acemoğlu Robinson 2012: 76). Polish extractive institutions originate both from the communist past (e.g. dominance of the state ownership and vested interests of stateowned enterprises) and from the period of systemic reforms. Influential special interests groups of so-called early winners have emerged which extract rent from the transition process itself. They support the reforms as long as they allow them to receive private gains, and they start to oppose them when the consolidation of the reform process begins to eliminate the sources of rents (Hellman 1998; Kozarzewski - Woodward 2006).

The weakness of this institutional setup in Poland does not seem to be uniform: there are areas were extracting institutions are relatively stronger (among others, 
in the state-controlled sector of the economy), while in other areas, especially during the first stages of transition, quite efficient inclusive institutions were formed - these areas being related, among others, to the private sector of the economy, including privatisation processes. As Woodruff (2004) points out, the consensual character of Polish privatisation, where potential shareholders and stakeholders reach an agreement, leads to the formation of stable property rights which nobody is interested to contest. Other factors also helped to make privatisation processes and the private sector as a whole much less prone to rent-seeking behaviour than the state-owned sector: the rather transparent character of privatisation procedures and refraining from giveaway privatisation schemes (except in mass privatisation, very limited in scope, a buyer had to pay for the privatised property), as well as the transparency of the emerging financial markets which, from the very beginning, were subject to strict rules and control with efficient enforcement mechanisms. Even early winner groups receive private gains not from ownership reforms themselves, but from refraining from them, through controlling the state property and blocking privatisation. The latter was, ironically, simplified by the consensual character of privatisation procedures.

\subsection{External and internal factors}

The Polish economy, as an open market one, is under the influence of international trends, global and regional crises, slowdowns, and recessions. So far, the economic development in Poland was, to a great extent, FDI-driven, which means even more dependence on the world economy, substantially limiting the Polish state's options for ownership policy. In fact, the speeding up of mainly FDIoriented privatisation in the late 1990s, with record-high privatisation revenues, would be impossible without a favourable situation on the global financial markets. The steep privatisation slowdown at the beginning of the 21 st century may be largely explained by foreign investors' falling demand for privatised property due to the global economic slowdown, and not only by the political changes in Poland resulting in the reluctant attitude towards privatisation.

Polish intellectuals were always open to ideas from the West, even in the Communist times, which contributed much to the reform concepts. The Balcerowicz Plan of 1989 was mainly a "domestic" product prepared predominantly by Polish experts, but its concept did not differ much from the mainstream reformist ideas of that time (e.g. the Washington Consensus). Throughout the whole transition period, a debate was held among experts and academia on the model for Polish reforms, with numerous references to the experience of both the most developed and emerging economies, and to the findings of the most renowned economists 
and political scientists all over the world. Therefore, the shift in the trends, both in economic policy and economic literature, towards market failure concepts could not have remained unnoticed - especially given the fact that "statist" economic ideas, as opposed to "liberal" ones, were always popular among a substantial part of Polish academia.

The third external factor which might have contributed to the policy shift in Poland was other countries' practical experience in managing the global crisis based mostly on the more active role of the state, including direct support to the entities such as big banks, production plants, etc., whose failure might bring too high costs for the economy.

There are important internal factors which might have contributed to the prostatist shift of the economic policy in Poland. One of the factors is the existence of powerful interest groups which extract rents from the state-controlled sector of the economy. Of course, the possibilities of getting rent are, to some extent, dependent on external factors, first of all on the situation on global markets, but both the sources of rent and the main rent-seeking groups are domestic. Potential foreign rent-seekers would rather be interested in privatisation and relaxing the state's grip on the economic processes than in more intervention of the Polish state.

Another inherently endogenous factor may be a widespread negative attitude towards privatisation in society, combined with the high popularity of a paternalistic state (Public Opinion Research Center 2009, 2015). It creates voters' demand for a statist social and economic policy; anti-privatisation and paternalistic vocabulary is widely used by competing political parties. Nevertheless, it seems that public sentiments are not among the main factors directly influencing the state's ownership policy. Comparing fluctuations of the public attitude towards privatisation with trends in the government's privatisation policy in 1990-2009, Bałtowski - Kozarzewski (2014: 392-393) came to the conclusion that it is public opinion that is influenced by the government's rhetoric rather than the government's policy being under the efficient pressure of voters' widespread statist attitudes. The recent developments seem to corroborate the hypothesis of the secondary importance of public opinion: the growing reluctance to privatise was not preceded by a corresponding growth of anti-privatisation sentiments in society (Ministry of Treasury 2015b).

Yet another argument in favour of the existence of powerful internal pro-statist factors is the different place state interventionism has in ownership policies in Poland and in the most developed European economies. Unlike the majority of developed economies, Poland has avoided giving direct support to failing industries and companies, or financial institutions. No bailouts took place. The main efforts of the Polish government were concentrated on maintaining the stability 
of public finances and of the financial system. The Polish economy went through the first wave of the global crisis relatively unharmed, and in 2009 it was the only European economy to record GDP growth. Apart from the government's anticrisis measures, the most often mentioned factors contributing to this exceptional result include the huge infusion of EU funds and the continuing inflow of FDI, a favourable situation on the relatively large domestic market, where population maintained strong internal demand, and the devaluation of the zloty, which helped to sustain exports (Ewing 2010; Mickiewicz - Douarin 2010; Sheets 2012). Thus, the better performance of the Polish economy during the global crisis does not seem to have stemmed from the earlier shifts to statist trends in the state's ownership policy. Besides, the recent more pronounced statist shift in the official discourse and the real economic policy in Poland took place when the world economy started to recover from the crisis, and governments began to revert to less interventionist policy, e.g. through re-activating the privatisation.

It should be also noted that besides the growing popularity of statism in economic theory and economic policy in the West, privatisation in these countries did not stop; it was just put on hold until the market situation improved. And, unlike in Poland, the strengthening of the state's role as an owner (e.g. through bailouts) was regarded more as a temporary anti-crisis measure than a long-term policy in these countries. Meanwhile, in Poland, statist trends do not seem to be merely tactics, but rather part of a long-term strategy, and it is privatisation that is regarded just as a tactical measure of last resort. The EU-15 countries privatised mostly when market conditions were stable and favourable, which, among others, gave the possibility to sell property at a higher price. The Polish government exhibited a more short-term behaviour, apparently selling property, more often than not, not when market conditions were favourable, but when it was extremely short of state budget proceeds (Figure 3).

\section{SOME CONCLUDING REMARKS AND DISCUSSION}

It can be argued that the ownership policy of the Polish government is determined by two major factors. The first one is the financial problems of the government - high public debt and budget deficit along with the need to finance reforms which forced it to look for additional sources of revenues. It is one of the causes of the fiscalisation of the government's privatisation policy during the 1990s and, conversely, of growing hopes in the 2010s that support for the state sector and new public investments will create new sources of revenues for the state budget. In the 21 st century, the privatisation policy became more reluctant but, most of the time, still dependent on fiscal reasoning in periods when the budget deficit 


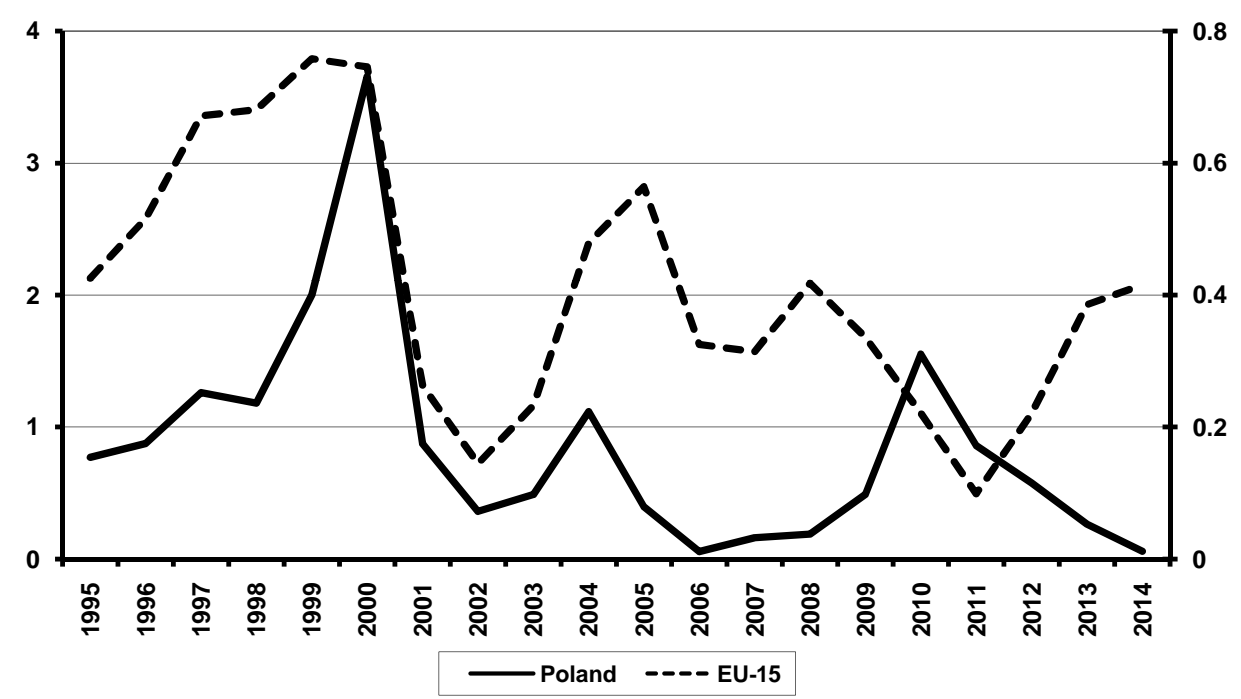

Figure 3. Revenues from privatisation in Poland (left axis) and the EU-15 states (right axis) (percent of GDP)

Source: Ministry of Treasury, The Privatisation Barometer (2015: 8), The PB Database (http://www.privatizationbarometer.net/database.php), Eurostat, own calculations.

was too high - which stimulated the cautious selling of some parts of the state property, preferably without losing control over it. However, there was a period of a complete lack of political will to privatise, and nowadays Poland is clearly entering such a period again. The second one is changing the paradigm of the role of the state in the economy: the state no longer shuns direct control over business entities, remaining a powerful (and privileged) player on the market in a longer perspective - and even expanding this role. It means a shift from privatisation to active state property management; since the early 2000 s, privatisation started to lose its function of being a cornerstone of reformist economic policy, its role becoming residual - as a part of the crisis management in order to solve fiscal problems.

The reasons for this statist shift cannot be reduced to ideological issues and rivalry between the main groups of Polish political elites because the evolution of the state's ownership policy seems to have many common features, regardless of the official rhetoric of the current ruling party or coalition. The recent period of accelerated statisation of the economic policy shows a particularly high degree of continuity, although the winners of the 2015 elections strongly stress their ideological detachment from their predecessors. 
Looking for the common roots of the ownership policy in Poland and its evolution, several factors with different degrees of significance have been identified. They were divided into two dichotomic groups: actions in "good faith" $v s$. pressure of vested interests, and endogenous factors $v s$. exogenous.

Within the first group, it seems that both factors have their impact on the state's ownership policy, although there is evidence that rent-seeking behaviour may play the leading role. In Poland, the state-controlled sector is the main source of rent, which makes privatisation a threat to rent-seekers rather than an additional source of private gains, unlike in some other post-communist countries, e.g. Russia and some other members of the CIS, where both privatisation and state property management were extensively used by rent-seekers. The main private interest groups are members of political elites, who treat control over the state property as a political bounty for election winners, governmental agencies that shape the ownership policy, and influential voter groups who receive rents in exchange for their political support to the giver. All these groups may have contributed to the deterioration of the privatisation policy (reducing it to the short-term goal of resolving the fiscal problems of the state) and eventually to its almost complete extinction as well as to the expanding state's ownership role.

Within the second dichotomy, a number of potentially important exogenous and endogenous factors have been studied. The external factors can be defined as Poland's economic and intellectual exposure to global trends: influence of the global economic processes, openness of Polish intellectuals to ideas from abroad, and transfer of knowledge on policy solutions. No matter how important they are, at the current stage of the research, arguments in favour of the more pronounced role of internal factors prevail. What represents the most important endogenous factor is extracting institutions which, to a large extent, control the state's ownership policy; one can also mention the role, to some extent, of public demand for a statist economic policy. The exogenous factors seem to play mostly an auxiliary role: increasing financial pressure, being a source of knowledge, serving as an example or a pretext.

These concluding remarks should be treated as only partially verified hypotheses rather than ultimate conclusions. We regard them as merely a step towards a deeper and more comprehensive understanding of the subject in question. Further study is needed in the following directions:

(1) A deeper analysis should be performed of the factors identified in this paper, from the perspective of their relative strength, mutual dependency, and specific mechanisms of exerting impact on the ownership policy (and, more broadly, on the level of statism in the Polish government's economic policy). Special attention should be paid to the factors that ensure the observed high degree of continuity of the ownership policy as well as factors that may induce its change. 
(2) Relations between endogenous and exogenous factors should be studied, among others, whether the extent to which their impact on the policy changes goes in the same direction is mutually conflicting or mutually reinforcing. Among exogenous factors, the role of the global crisis in the policy change should be studied in more detail, first of all to what extent pro-statist changes in the economic policy of the Polish state could be efficient as anti-crisis measures.

(3) The endogenous factor of the Polish political elites' good faith should be studied more thoroughly, first of all in the areas of the state's ownership policy where this factor may play an important role, and its impact on the ownership policy effects, including side effects such as gains for various interest groups.

(4) A deeper study of the role of rent-seeking in the state's ownership policy is needed, including its scale, sources and types of rents, and ways to extract them, categories of rent-seekers as well as the evolution of rent sources, rent-seeking groups, and their behaviour.

(5) Possible ways, goals, and beneficiaries of the rent-motivated transfer of resources from state-controlled companies should be examined more closely in this context, including sports and cultural events sponsorship, advertising campaigns in media, outsourcing contracts, etc.

(6) The analysis should be extended to include other emerging economies (in CEE and beyond) to answer the question of to what extent the evolution of the ownership policy, and of the factors behind it, have a unique character in Poland, and to what extent it is determined by the level of the country's economic and institutional development.

\section{REFERENCES}

Acemoğlu, D. - Robinson, J. A. (2012): Why Nations Fail: The Origins of Power, Prosperity, and Poverty. New York: Crown Publishers.

Bałtowski, M. - Kozarzewski, P. (2014): Zmiana własnościowa polskiej gospodarki 1989-2013 (Ownership Change in the Polish Economy 1989-2013). Warsaw: PWE.

Bałtowski, M. - Kozarzewski, P. (2016): Formal and Real Ownership Structure of the Polish Economy. State-Owned versus State-Controlled Enterprises. Post-Communist Economies, 28(3): 405-419.

Błaszczyk, B. (ed.) (2004): Koszty spowolnienia prywatyzacji (Costs of the Privatisation Slowdown). Zeszyty BRE Bank-CASE, 70: 1-112.

Bortolotti, B. - Faccio, M. (2004): Reluctant Privatisation. Fondazione Eni Enrico Mattei Nota di Lavoro, 130: 1-39.

Bortolotti, B. - Pinotti, P. (2003): The Political Economy of Privatisation. Fondazione Eni Enrico Mattei Working Paper, 45: 1-45.

CEEP (2000): Development of Enterprises of Public Participation and of General Economic Interest in Europe since 1996. CEEP Statistical Review, Brussels: European Centre of Employers and Enterprises Providing Public Services. 
Central Statistical Office (2014a): Statistical Yearbook of the Republic of Poland. Warsaw: GUS.

Ewing, J. (2010): Poland's Currency Lifts Economy. New York Times, December 6 (available at: http://www.nytimes.com/2010/12/07/business/global/07zloty.html).

Flores-Macias, F. - Musacchio, A. (2009): The Return of State-Owned Enterprises. Harvard International Review, April 4 (available at: http://hir.harvard.edu/the-return-of-state-ownedenterprises).

Głombicki, Ł. (2012): Rozmnożenie złotówki - ministrowie finansów i skarbu o planach z exposé premiera (Multiplication of Zloty - Ministers of Finance and Treasury about Plans from the Prime Minister's Policy Statement). Gazeta.pl, October 13 (available at: http://wiadomosci.gazeta.pl/wiadomosci/1,114873,12664062,_Rozmnozenie_zlotowki__ministrowie_ finansow_i_skarbu.html).

Hellman, J. S. (1998): Winners Take All: The Politics of Partial Reform in Post-Communist Transition. World Politics, 50(2): 203-234.

Jackiewicz, D. (2016): Wygaszamy proces prywatyzacji (We are Extinguishing the Privatisation Process). Rzeczpospolita, February 26 (available at: http://www.rp.pl/Prywatyzacja/302269890Jackiewicz-wygaszamy-proces-prywatyzacji.html).

Jarosz, M. (2001): Rady nadzorcze w kleszczach interesów partyjnych i grupowych (Supervisory Boards in the Grip of Party and Group Interests). In: Jarosz, M. (ed.): Manowce polskiej prywatyzacji (Polish Privatisation - Where did It Go Astray?). Warsaw: ISP PAN, pp. 44-71.

Kawalec, S. (2011): Udomowić banki. Powinny być pod krajową kontrolą, a nie zagraniczną (To Domesticate Banks. They Are to Be under Our Control, and not the Foreign One). Gazeta Wyborcza, November 7 (available at: http://wyborcza.biz/biznes/1,101716,10599121,Udomow ic_banki_Powinny_byc_pod_krajowa_kontrola_html).

Kochanowicz, J. - Kozarzewski, P. - Woodward, R. (2005): Understanding Reform: The Case of Poland. CASE Reports, 59: 1-106.

Kowalski, P. - Büge, M. - Sztajerowska, M. - Egeland, M. (2013): State-Owned Enterprises: Trade Effects and Policy Implications. OECD Trade Policy Paper, 147: 2-46.

Kozarzewski, P. - Woodward, R. (2006): The Reform Process in Post-Communist Transition: Understanding Reform in Eastern and Central Europe and the Commonwealth of Independent States. In: Fanelli, J. M. - McMahon, G. (eds): Understanding Market Reforms.Houndmills and New York: Palgrave Macmillan, Vol. 2. pp. 141-192.

Krugman, P. (2009): How did Economists Get It so Wrong? The New York Times Magazine, September 2 (available at: http://www.nytimes.com/2009/09/06/magazine/ 06Economic-t.html?_r=0).

Mączyńska, E. (2016): Neoliberalizm jest groźny dla rozwoju kraju (Neo-Liberalism Is Dangerous for the Development of the Country). Rzeczpospolita, June 15.

Mickiewicz, T. - Douarin, E. (2010): Economics of Institutional Change: Central and Eastern Europe Revisited. Basingstoke: Palgrave Macmillan.

Ministry of Development (2016): Strategia na rzecz Odpowiedzialnego Rozwoju (Strategy for the Responsible Development). Warsaw: Ministerstwo Rozwoju, 29 July.

Ministry of Treasury (2011): Badanie $i$ analiza procesów prywatyzacyjnych $w$ ramach wykonywania planu prywatyzacji na lata 2008-2011. Raport szczególowy (Study and Analysis of the Privatisation Processes within the Implementation of the Privatisation Plan for 208-2011. The Detailed Report). Warsaw: MSP.

Ministry of Treasury (2015a): Kierunki prywatyzacji majątku Skarbu Państwa w 2016 r. (Directions of Privatisation of the State Treasure Owned Property in 2016). Warsaw: MSP.

Ministry of Treasury (2015b): Raport o ekonomicznych, finansowych i spolecznych skutkach prywatyzacji w roku 2014 (Report on Economic, Financial, and Social Effects of Privatisation in 2014). Warsaw: MSP. 
Morawiecki, M. (2015): W polskiej gospodarce za mało „polskiej gospodarki” (There is not Enough of "Polish Economy" in the Polish Economy). Bankier.pl, December 7 (available at: http:// www.bankier.pl/wiadomosc/Morawiecki-W-polskiej-gospodarce-za-malo-polskiej-gospodarki3452797.html).

Mühlenkamp, H. (2015): From State to Market Revisited: A Reassessment of the Empirical Evidence on the Efficiency of Public (and Privately-Owned) Enterprises. Annals of Public and Cooperative Economics, 86(4): 535-557.

Murrell, P. - Wang, Y. (1993): When Privatisation Should be Delayed: The Effect of Communist Legacies on Organizational and Institutional Reforms. Journal of Comparative Economics, 17(2): 386-406.

Musacchio, A. - Lazzarini, S. G. (2012): Leviathan in Business: Varieties of State Capitalism and Their Implications for Economic Performance. Harvard Business School Working Paper, 12(108): $1-60$.

Patena, W. - Błaszczyk, B. (2016): Post-Privatisation Corporate Performance: Evidence from Companies Privatized in Poland in 2008-2011. Studia Ekonomiczne, 2(LXXXIX), 199-221.

Prusek, T. - Bielecki, T. (2012): „Inwestycje Polskie”? Niech państwo zainwestuje, ale później sprzeda. Rozmowa z Jackiem Sochą ("Polish Investments"? Let the State Invest, but Sell Afterwards. An Interview with Jacek Socha). Wyborcza.biz, October 27 (available at: http://wyborcza. biz/biznes/1,101562,12748944,Socha_Inwestycje_Polskie__Niech_panstwo_zainwestuje_. html).

Public Opinion Research Center (2009): Prywatyzacja - oceny, skojarzenia, oczekiwania i obawy (Privatisation - Assessments, Associations, Expectations, and Concerns). Warsaw: CBOS, October.

Public Opinion Research Center (2015): Co różni zwolenników lewicy, centrum i prawicy? (What Is the Difference between Supporters of the Left, Center and Right?). Warsaw: CBOS, October.

Radygin, A. - Entov, R. (2014): The Fundamental Privatisation Theorem: Ideology, Evolution, Practice. SSRN (available at: http://papers.ssrn.com/sol3/papers.cfm?abstract_id=2398960).

Senderski, M. (2015): Inhibited Privatisation: A Hurdle Race over Vested Interests. European Journal of Government and Economics, 4(1): 46-66.

Stiglitz, J. E. (2009): Regulation and the Theory of Market and Government Failure. In: Moss, D. Cisternino, J. (eds): New Perspectives on Regulation. Cambridge, MA: The Tobin Project.

Sudak, I. (2015): PiS rozliczy prywatyzację poprzedników (PiS Will Appraise Its Predecessors' Privatisation Deals). Wyborcza.biz, December 19 (available at: http://wyborcza.biz/ biznes/1,100896,19315688,pis-rozliczy-prywatyzacje-poprzednikow.html).

Szanyi, M. (2016): The Reversal of the Privatisation Logic in Central European Transition Economies (An Essay). Acta Oeconomica, 66(1): 33-55.

The Privatisation Barometer (2015): The PB Report 2013/2014. Milano (available at: http://www. privatisationbarometer.net/PUB/NL/5/3/PB AR2013-2014.pdf).

Woodruff, D. M. (2004): Property Rights in Context: Privatisation's Legacy for Corporate Legality in Poland and Russia. Studies in Comparative International Development, (38)4: 82-108. 